\title{
移植腎の髓質機能に関する臨床的観察
}

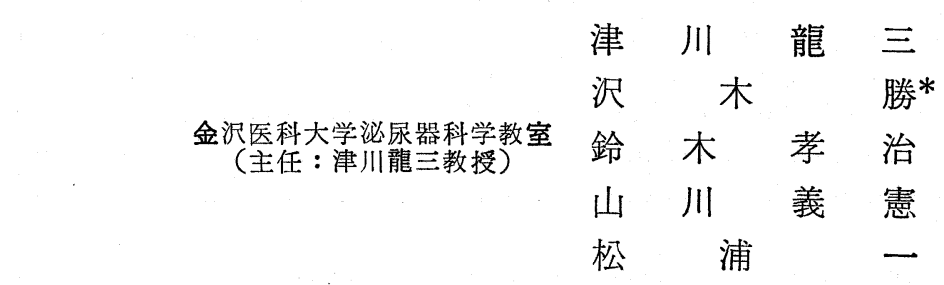

\section{A CLINICAL OBSERVATION OF RENAL MEDULLARY FUNCTION IN RENAL ALLOTRANSPLANTATION}

\author{
Ryuzo Tsugawa, Masaru Sawaki, Koji Suzuki, Yoshinori Yamakawa and \\ Hajime Matsuura. \\ Department of Urology, Kanazawa Medical University, Uchinada Japan
}

(Director: Prof. R. Tsugawa)

Recently, to evaluate the transplanted renal function, creatinine clearance and serum creatinine, which show cortical function, have been preferred. But medullary function is also important for proper evaluation.

For this purpose, urinary concentration tests, response of urinary volume and osmolarity by pitressin loading under water diuresis were performed. Concerning with these tests, cystoscopic examinations for new ureteral orifice, excretory urography for the transplanted kidney and ureter, and voiding cystography for vesicoureteral reflux were also made.

Twenty-five patients had renal transplantation (living related) in Kanazawa Medical University Hospital during the period of March 1975 through December 1978. One of them died due to duodenal perforation and sepsis, and the graft of one patient was removed due to hyperacute rejection two days after the operation. Therefore, twenty-three cases were studied, but the same set of examinations could not be performed in all cases.

In donors, examinations were made before nephrectomy and two weeks after nephrectomy, and in recipients, 40-80 days after transplantation (discharged from the hospital), as well as one year, two years and three years thereafter. Concentration tests were made by the Fishberg's method and pitressin loading tests were done by a modification of Massry's method. About 500-600 ml of water was given orally, $5 \%$ glucose solution was infused intravenously, and urinary volume was stable at $10 \mathrm{ml}$ per one minute. Then, as the first loading one miliunit of pitressin (water soluble) per $1 \mathrm{~kg}$ (body weight) was injected intravenously, urinary volume and osmolarity were measured four times every 15 minutes, and then 10.0 miliunits of pitressin was given as the second loading. In normal cases (such as donors), urinary volume decreased, and osmolarity increased more than $400 \mathrm{mOsm} / \mathrm{kg}$ by the first loading of pitressin. By the second loading, urinary volume decreased, and osmolarity was more than $600-700 \mathrm{mOsm} / \mathrm{kg}$.

As for the results of examinations, concentration tests which were evaluated by specific gravity showed a few differences between before and after nephrectomy of donors. But, when they were evaluated by osmolarity, no statistic difference was noticed. In recipients, whose histocompatibility was HLA-identical and showed no rejection, specific gravity (osmolarity) of urine was normal. But, in recipients of HLA-haloidentical and showing rejection crisis, specific gravity (osmolarity) fixed in the lower border of the normal range or in the abnormal range.

Response for pitressin loading showed almost the same pattern in donors and recipients of HLA-

* 現金沢大学泌尿器科 
identical. It is supposed that renal response has its individual character. When a removed kidney is transplanted to recipient's iliac fossa or, in other words, "new circumstance", its character is handed down. On the other hand, when the rejection crisis occurs, the pattern of response changes and the maximum point of osmolarity decreases. These data may mean that rejection crisis gives damages to the renal medulla which is also the target area of pitressin.

By calculation of osmolar clearance per GFR of the kidney, when rejection crisis occurs, it was higher than in normal cases. It means that the kidney is in an overworking state per nephron. In donors, who are over 50 years old, osmolar clearance has a tendency to show a higher increase than in preoperative condition.

By observing the appearance of the new ureteral orifice, the cases of HLA-identical showed a smooth extention of ureteral and vesical mucosa each other and a good normal vascularity. But the cases of HLA-haploidentical showed an edematous orifice and an unnatural state in recipient's vesical mucosa.

Excretory urography revealed a normal renal function and no dilatation of ureter. Voiding cystography revealed that vesicoureteral reflux did not exist in the transplanted ureter but in the bilateral own ureters of two cases.

In the urological field, urinary stasis caused by various factors is usually understood as the term "obstructive nephropathy". In order to explain the condition, evaluation of medullar function has a very important significance. Generally, it is considered that, for the purpose to diagnose renal functional failure of recipients, the following three possibilities must be checked: 1) prerenal, vascular complication, 2) renal, rejection and ATN, 3) post renal, trouble of the ureter and ureteral orifice. Among these three factors, the test of medullar function is closely related to 3) and 2). Therefore, routine evaluation of medullar function should be emphasized to have an important significance as that of cortical function.

\section{緒 言}

腎移植の進歩は近年著しく，慢性腎不全の治療法とし て今やその地位を確立したといえる. その成績の評価の 基準は, 生存率は当然ながら, 移植腎機能がどの程度保 たれているかがより本質的というべきであろう。

移植腎機能を評価するのに従来クレアチニンクリアラ ンス，血清クレアチニン值で表示されているが，腎と招 ける水バランスの調節すなわら濃縮稀积機構のチェック もまた重要な項目であろら。

著者らは従来から腎移植例に対しいわゆる濃縮試験, 拉よび水利尿下に拈ける水溶性ピトレッシン負荷テスト を行つてきたのでその結果を報告し，これに関連すると 思われる移植尿管口の内視鏡的所見, 膀脱尿管逆流現象 についても述べる.

\section{対象と方法}

当院腎移植チームによつて実施された腎移植は, 1975 年 3 月以来1978年12月末までに25例に対し25回でいずれ も血縁者間生体腎移植である.このうち死亡例 1 , 超急 性拒絶反応によつて 2 日後洛植腎摘除を行つた 1 例を 除き述べるが，検查項目によつて第 1 例から実施してい ないものもあるので症例数は異なる.
提供者については術前術後, 受腎者に対しては退院前 (術後 40 〜 80 日目)，拉よび術後一定期間を設けて検索 した. 濃縮能については成書 ${ }^{1}$ に記載されている方法で 尿比重又は最高浸透压をるつて判定した. 稀釈能につい ては次に述べるピトレッシン負荷テストに捺ける負荷直 前の利尿時の尿をるつて測定した．ピトレッシン負荷 テストについての著者らの方法は Fig. 1 のごとくであ る. 本法は Massry 2) の述べた方法を改変したもので, 水の飲用拉よび $5 \%$ ブドウ糖液の持続点滴により， 1 分 に約 $10 \mathrm{ml}$ の利尿をみた時点で $1.0 \mathrm{mu} / \mathrm{kg}$ の水溶性ピト レッシンを回路内に注入し，15分ごとに 4 回採尿し尿量 と浸透圧を測定する。次いで $10.0 \mathrm{mu} / \mathrm{kg}$ の負荷を行い，

同様に 4 回採尿する. 著者ら ${ }^{3)}$ の成績によれば，ピトレ ッシン負荷によりその都度尿量は激減し，尿の浸透圧は 上昇する.第 1 の負荷では $400 \mathrm{mOsm} / \mathrm{kg}$ 以上飞達する. 第 2 の負荷では 600 700 mOsm/kg 飞達する. な抒水分 の負荷は検査終了まで続ける。また最近の症例について は GFR 当りの浸透圧クリアランスを検討した。すなわ ち第 1 のピトレッシン負荷前の15分間についてと第 2 の 負荷後で尿が最も濃縮される時期，すなわち，16分目か ら30分目までの15分間についても尿特よび血清に括ける 
Fig. 1 Outline of pitressin loading test （ピトレッシン負荷テストの概要）

\section{実施方法}

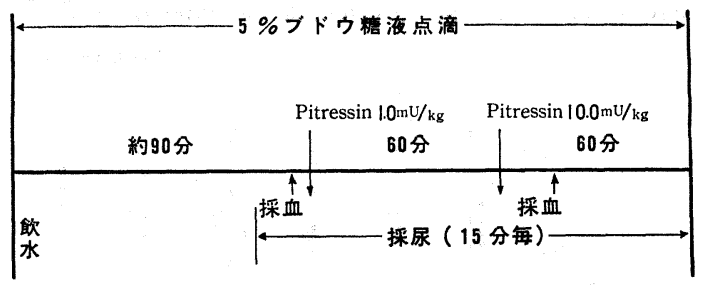

浸透圧，クレアチニン値，尿量から計算した。

また受腎者については膀胱鏡検査による尿管の形態 と, X線テレビおよび撮影による膀胱充満時拉よび排尿 時に打ける膀胱尿管逆流現象の有無, および排泄性尿路 造影による尿管拆張の有無について検討した ${ }^{4)}$.

\section{成 縉}

術後 1 年以上追求できた例の濃縮能は Fig. 2 のごと く, 提供者の術前後を最高比重でみると差はあるが, 最 高漫透圧をもつての表現法で推計学的処理をすると有意 差はみられない，受腎者についてみると，拒絶反応を示 さない群については退院時， 1 年目， 2 年目， 3 年目 （4 例）を通じて正常值を示しているが，拒絶反応を示 した例は低下したところで固定している．2年目で最高 浸透圧298を示した例は，血清クレアチニンも $10 \mathrm{mg} / \mathrm{dl}$ に近づき，移植腎摘除を行つた。稀釈能については最近 の症例を主体にして観察した結果では，提供者術前を基 準にすると，提供者の術後，受腎者退院時， 1 年目の順 にその能力は低下する傾向にある。

ピトレッシンに対する反応であるが，まず個々の例に つき提示する。

Fig. 2 Concentration test.

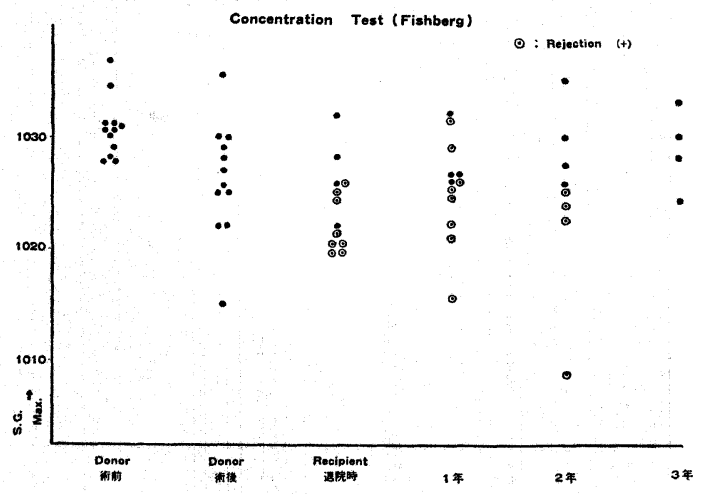

第 1 例は 30 歳の姉を提供者として和植を実施した identical sibling のペアである. Fig. 3 の左側は提供者 のもので第 1 の負荷によつて一旦上昇した浸透圧は第 2 負荷前には再び下降しており，第 2 の負荷にあらためて 反応する. 同図の右側は受腎者の退院前のものであり, その反応様式はきわめて類似している，IVP，核医学的 所見などは全く正常である.

第 2 例は34歳の姉を提供者としたペアで，やはり identical sibling である. Fig. 4 の左側は提供者のもの で第 1 の負荷によつて一旦上昇した漫透圧はこの間の水 分負荷の継続があるのにもかかわらず浸透圧はそのまま 上昇して第 2 回目の負荷にさらに反応している. 受腎者 についてみると，退院時のものは Fig. 4 の右側のごと くで，この間経過順調で拒絶反応もなく，X線学的执よ び核医学的検査には異常ない。すなわちこれら 2 例をみ ると，ピトレッシン負荷に対する尿量減少および浸透圧 上昇の態度はきわめてょく類似している，次に拒絶反応

Fig. 3 Pitressin loading test, showed almost the same pattern in donor and recipient (HLA-identical).

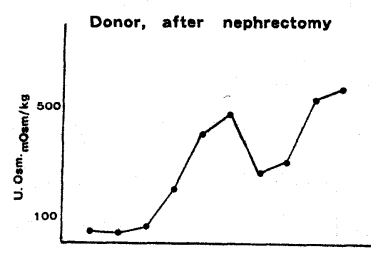

Recipient, $1 \mathrm{M}$ after transplantation (LD.4)
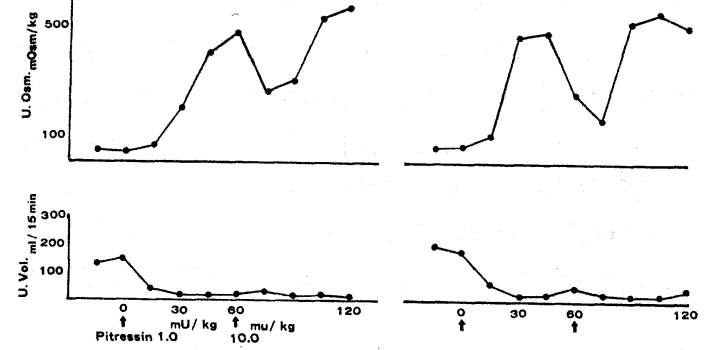

Fig. 4 Pitressin loading test, showed almost the same pattern, sister to brother (HLA-identical).

(LD. 3)
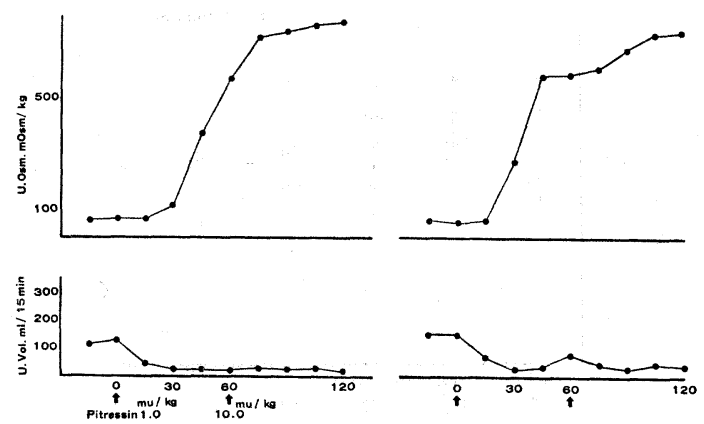
Fig. 5 Pitressin loading test, showed decrease of response, mother to son (HLA-haploidentical), in whom acute rejection occurred twice.

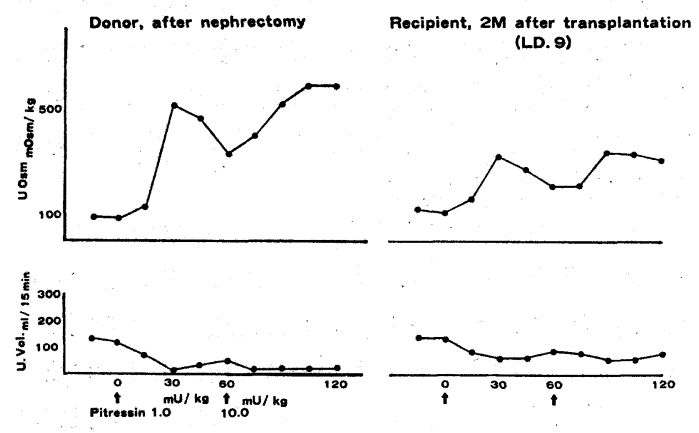

を示した例の反応様式の変化をみると，まず腎提供者に ついては Fig. 5 の左側のごとくである. 本例は急性拒 絶反応を 2 回発症し,メチルプレドニソロン大量療法で 対処したが，同図右側は退院時の状況である。この例は 2 年目ごろには，クレアチニンは $9.8 \mathrm{mg} / \mathrm{dl}$ ，と上昇し， 第 1 の負荷に対しては漫透圧は231, 第 2 の負荷に 対し ては272の上昇をみるのみとなつた。この例はこの值を 示したあと 1 カ月目に人工透析に戻り移植腎摘除を行つ た.

ピトレッシンに対する反応を全体的にみると Fig. 6 のごとくまず $1.0 \mathrm{mu} / \mathrm{kg}$ 負荷後の尿浸透圧は提供者の術 前術後では有意差はないが，受腎者については拒絶反応 のみられなかつた群では 3 年目まで有意差なく経過した が，拒絶反応をみた群では有意差をもつて低下する。ま た $10.0 \mathrm{mu} / \mathrm{kg}$ 負荷時の反応についてみると，Fig. 7 の ように提供者については, $1.0 \mathrm{mu} / \mathrm{kg}$ 負荷時と同様に差

Fig. 6 Maximum of urine osmolarity by administration of pitressin $(1.0 \mathrm{mu} / \mathrm{kg})$ showed low response in the group of rejection.

Max. of Urine Osm. by administration of Pitressin $1.0^{\mathrm{mu} / \mathrm{kg}}$

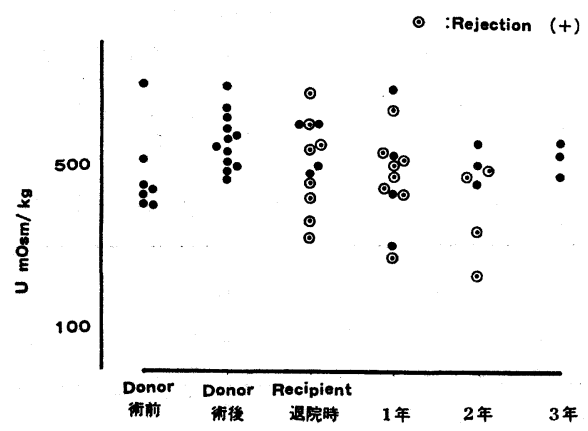

Fig. 7 Maximum of urine osmolarity by administration of pitressin $(10.0 \mathrm{mu} / \mathrm{kg})$ showed low response in the group of rejection (HLA-haploidentical).

Max. of Urine Osm. by administration of Pitressin $10.0^{\mathrm{mu} / \mathrm{kg}}$ ○ : Rejection (+)

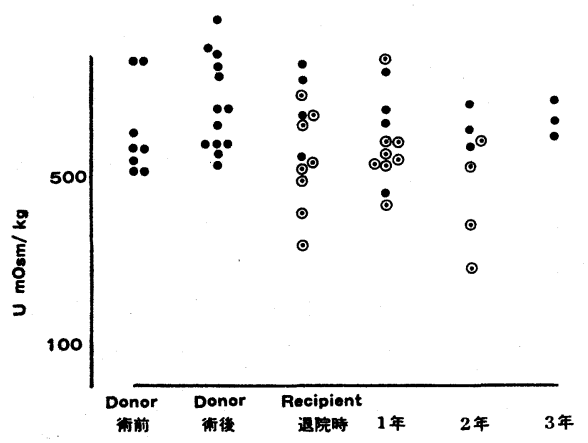

がなく，受腎者体内に打ける運命としては，3年目まで を追求し党た拒絶反応をみない群では全く安定して抹 り，拒絶反応をみた例では提供者に比して有意な低下を みている。

次に GFR 当りの浸透圧クリアランスをみると Fig. 8 のごとくで，まず提供者に拈いてピトレッシン負荷前の 利尿時に括いては，術前すなわち両腎の場合と術後すな わち単腎の場合を比較すると，大体に拈いて有意差はな いが，一部上昇を示すものがあり，この傾向は50歳以上 の例にみられた. 受腎者に执いては拒絶反応なく 2 年, 3 年と経過した症例をみると, 術前の提供者集団の值と 同様のレベルとなつている，また拒絶反応をみた群をみ ると退院時， 1 年， 2 年目に羊いては高值を示し，単位

Fig. 8 Osmolar clearance per GFR before administration of pitressin (state of water diuresis), tends to high level in the group of rejecetion.

Cosm/ GFR $\times 100$ : before administration of Pitressin
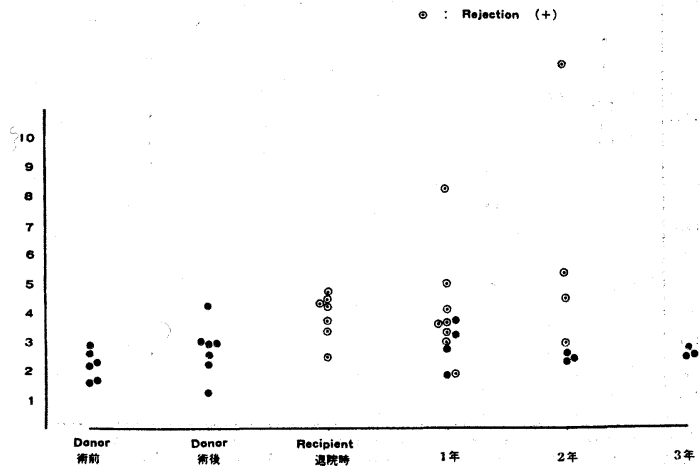
Fig. 9 Osmolar clearance per GFR after administration of pitressin $(10.0 \mathrm{mu} / \mathrm{kg})$ tends to high level in the group of rejection.

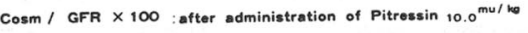

$\odot$ : Rejeetion (+)

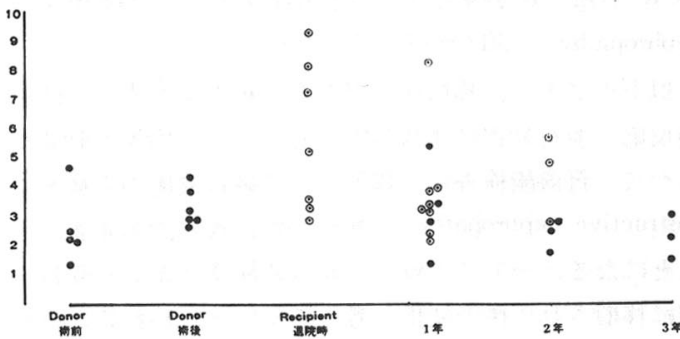

ネフロン当りの仕导の量は多いことがわかる。

次に体重 $\mathrm{kg}$ 当り，10.0mu のピトレッシンを負荷 し，15分間採尿したあとの次の15分間，すなわち最も尿 量が減少しその浸透圧が最も上昇する時期についてみ ると Fig. 9 のごとくで，まず拒絶反応をみなかつた群 では提供者術前 (両腎), 術後 (単腎) と受腎者の 退院 時, 1 年後, 2 年後, 3 年後では差がなく, 一方拒絶反 応をみた群では提供者においては術前に比し術後でやや 高く, これが 2 年までの追跡では上昇を示している.

Fig. 10 Ureteral orifice shows natural appearance and normal vascularity (HLA-identical), LD 1.

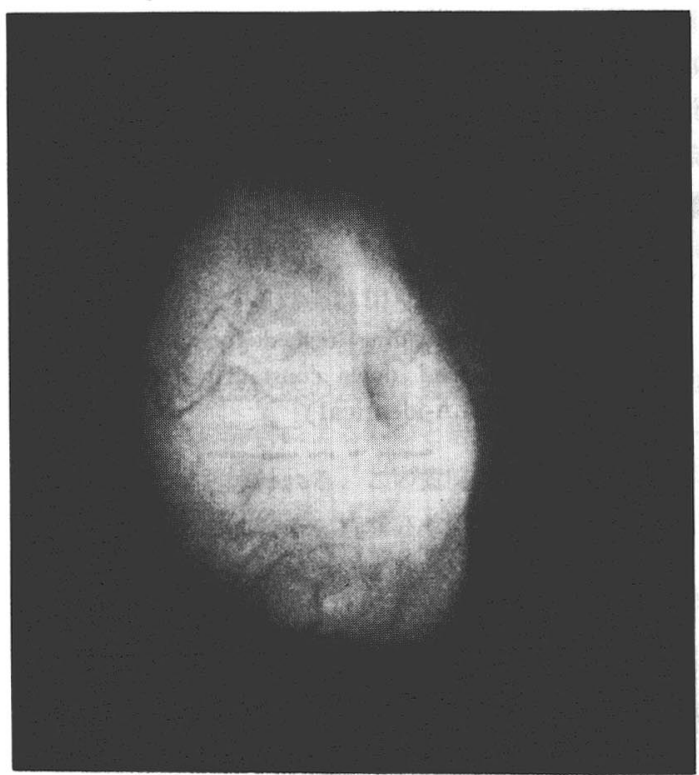

Fig. 11 Ureteral orifice shows unnatural appearance, edematous and poor vascularity (HLA-haploidentical), LD 17.

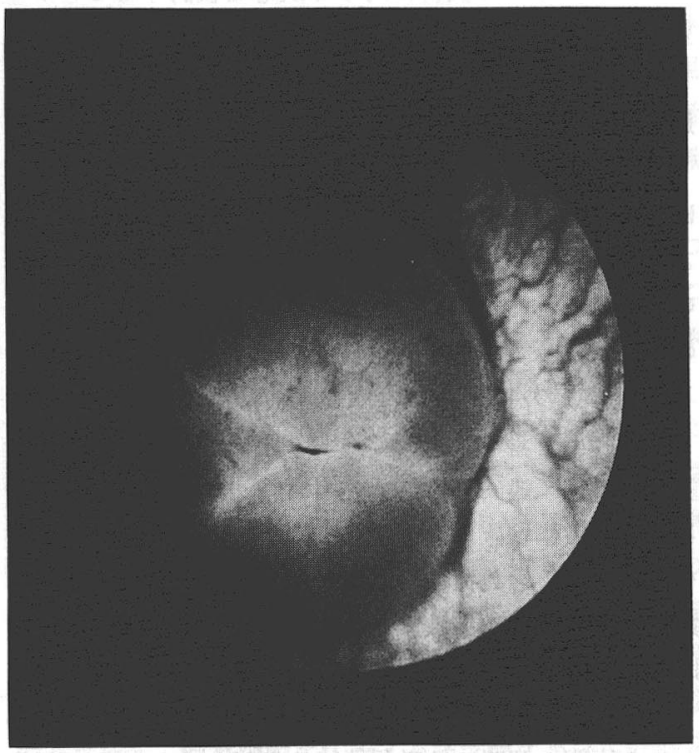

膀胱鏡椿査による尿管口の観察では，拒絶反応のない 群では Fig. 10 のように新尿管口に扩るる翻転された尿 管粘膜（われわれは cuff を形成している）に対し，凬 囲よりの血管の進入も認められ，膀胼粘膜一尿管粘膜の 移行がスムーズである。一方，拒絶反応を認める例では Fig. 11 のように浮腫状で膀胱粘膜との移行性もスムー ズではなく，「とつてつけた感じ」がする。

$\mathrm{X}$ 線検查では膀胱尿管逆流現象は 2 例において両側固 有尿管にみられたが，移植腎にはみられなかつた。排泄 性尿路造影では全例腎杯腎血尿管像は正常であつた。

\section{考按}

移植腎機能を評価するのに, 従来血清クレアチニン, クレアチニンクリアランスで代表されていることは周知 の事実で，この検査は腎の皮質機能を示すbのである. Ogden ${ }^{5)}$ は提供者，受腎者の28例をペアで観察し，糸球 体濾過值之有効腎血漿流量から提供者では術前の 7 割, 受腎者は提供者の術後の 9 割弱としている.しかし全体 の機能を推論するときは䯣質の機能をも同時に評価する 必要があるのではなかららか，小川 ${ }^{6)}$ は髄質機能障害の 疑われる症例に対する検査法は次のようにすべきである 之し, 1) 臨床幑候, 2) 尿量, 尿浸透圧 (尿比重), 3）血清尿素窒素，クレアチニンおよび血清電解質，著 明な多尿の場合には，4） $\mathrm{ADH}$ 試験（または濃縮試 
験），5） 尿中電解質，遺伝性尿細管障害が 疑われる場 合は $\mathrm{NH}_{4} \mathrm{Cl}$ 負荷試験その他としている.すなわち濃縮 能，ピトレッシン負荷に対する反応を検討することが重 要と思われる.

まず濃縮能についていえば，腎提供者の両腎存在時に 比して，術後単腎となつても不変でそれをうけてスター トした受腎者は退院時に抢いてやや低下し以後横ばい又 は低下という状況である。このことは一般の腎不全患者 と同様の経過を示するのと考兄られる。しかし安東ら の述べるごとく, Fishberg 濃縮試験時の尿比重は腎䯣質 の機能ばかりではなく, 皮質機能その他の因子女関与す るので, この点は念頭に抏く必要がある.

次にピトレッシン負荷に対する尿量および尿漫透圧の 変動について述べてみたい. Massry は，前立腺癌によ る尿閉患者に留置カテーテルを置き, 腎機能の回復状況 をピトレッシン負荷に対する反応を示標として追跡し，

鈍い反応から漸次鋭敏になるとした。このよらな腎後性 因子による障害は, obstructive nephropathy といら概念 で把握されて，注目すべき領域となつてきている。しか もこの病態の解明には髄質機能の解析なくしては不可能 である.最もよく遭遇するのは子宮癌末期にみられる下 部尿管の通過障害によるもので, 腎造瘦術を行つた症例 の術前, 術後を比較すると明らかな差がみられる．参考 のために子宮癌末期に扮いて腎後性腎不全を来し, 腎造 瘦術を行つた例の術前術後を Fig. 12 亿示した. 左右を 比較すれば反応性の回復を知ることができる.

“腎移植といら治療法をこの点からスポットを当ててみ ると，移植腎は拒絶反応，血管吻合部障害などの腎実質 性，腎前性因子による機能不全と同様，尿管の 栄養状 態，尿管膀胱新吻合術の結果如何によつては obstructive

Fig. 12 Terminal stage of uterine cancer, pitressin loading test shows poor response before nephrostomy, but after nephrostomy, recovering response is noticed.
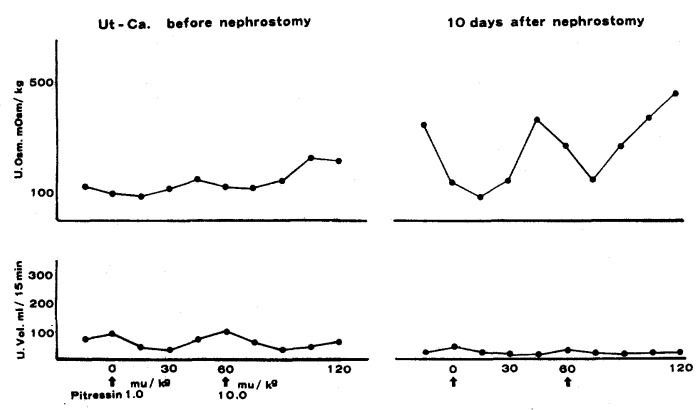

nephropathy を惹起する条件も十分に持つているとい兄 よう。またこの部は受腎者の膀胱と提供者由来の尿管の 接点であることも忘れてはならない点である，移植腎の 尿管を膀脱に吻合する場合，粘膜下トンネル法が広く行 われている。しかしこの方法は，VUR を回避する一方 では狭窄も起こしうる危険がある。逆化手技が未熟で VUR が起これば腎孟への逆圧負荷を来して obstructive nephropathy と同様の影響が拈よぶ.

以上のごとく，移植例に対しこの検查を行うことは拒 絶反応，血行障害による障害を知ることと同等の価值を もつて, 腎機能検查の一環としての䯣質機能の点検と, obstructive nephropathy が加わつたか否かの追求といら

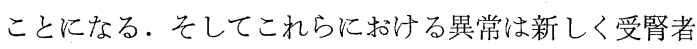
内に移植されて後の変化と考光てよいと思われる，その 根拠は既に成績の項で，identical sibling の例で示した ごとく，腎提供者から受腎者に移植されたあとの移植腎 のピトレッシンに対する反応は, 腎提供者の反応パター ンとさわめてょく類似している。このことはとれぞれの 個体についてい党ば，腎そのものがその個人について特 有な反応，いわゆる個性を持つておうり，それが新しい環 境，すなわち受腎者の体内にあつてもその個性的なパ ターンを伝承することを示している．今回の成績はその ことを実際に観察できたことで意義が深い。またこのよ らな伝承といら事実は，実際には他の機能検査にも存在 すると思われるが，数值で表現されてしまうものであれ ば，結局把握できないものと思われる。その点本法はグ ラフで表現され，長期追跡の際には提供者のポターン が常にいわゆる「手本」となることはいらまですない。

Fig. 13 亿艺の 1 例を示す. 提供者の術後, 受腎者の退 院時， 3 年目をまとめて示したが， 1 年目， 2 年目も同 様のパターンを示した.

ピトレッシン負荷テストについては著者らの 1 人津

Fig. 13 Pitressin loading test, donor's pattern of response is handed down constantly to recipient for 3 years (HLA-identical)

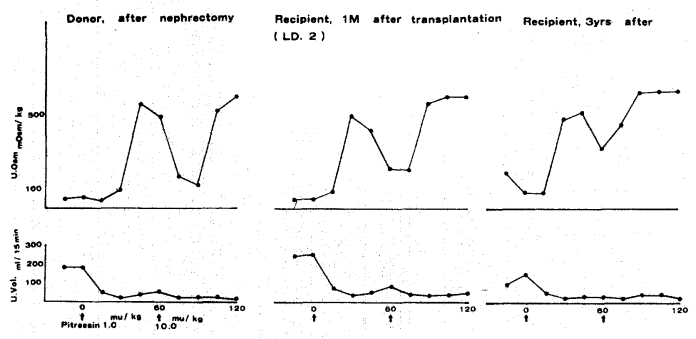


川が当初子宮癌末期などのいわゆる obstructive nephropathy に拈いて変動することを報告してきた。そして, この変動が, クレアチニンの変動にさきがけてみられた ことも興味ある点として強調した。

今回は，これを腎移植症例に执いて実施したが，この ことは, 同一腎に対し，宿主を変兄，同一条件下で検索 し，そのパターンを比較するといら特殊な設定下に行つ たことになりしかも両者に高い相関, 類似珄を認めたこ とは，当初目的とした髄質機能，主として濃縮力をみる といら目的もさることながら生体臟器のもつ個人差の存 在を想像させ，きわめて興味深いことは前述した。さら には移植腎の状況を知るために行ら腎生検に和いては恐 らく到達しえない腎盂に接する部分である髄質の状沉を 本法で推定できることも有用と考穴られる。 また GFR 当りの Cosm についてはピトレッシンに対する反応は一 見正常と思われる例でも，結局かなりの overwork を強 いられていることが判明し，この検査法が腎機能の分析 に有用であることを証明したことになる. Williams ら は最初の 4 カ月間での拒絶反応の状況とそれより18カ月 後の予後を述べている. Group I としてよい適合性を有 し，この期間中に急性拒絶反応なく，蛋白尿をみなかつ たものは $100 \%$, Group II として, 1 回のみの発症で30日 以内に治療し，乙かも透析不要であつたものは $84 \%$, Group III として, 1 回以上のものは50\%，Group IVとし ては，拒続反応が30日以上続いたもの，透析を要したも の, 4 カ月以後に起こつたもの, 術後 1 週以内に起こつ

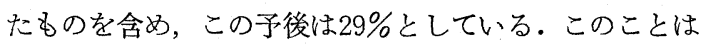
2 回以上発症したものの予後は50\%以下であることを示 し, 著者らの Cosm/GFR の成績からみてもその傾向を らかがわせる。

さて, 一方に括いて実施した尿管口の形態の観察, 排 泄性尿路造影, 膀胱尿管逆流現象 (VUR) の検索では 通過障害を証明する所見はなく, VUR は固有腎への 2 例をみたのみであつた. 従つて前述の濃縮能, ピトレッ シン負荷に対する反応の差異は通過障害によるものでは なく，腎実質の障害によるるのと思われる。すなわち拒 絶反応が主体と思われる。この意味で濃縮試験は簡単な 外来検査として，検体を持参させ，諸種の定期的採血と 併施することも意義がある。

な打尿管機能については，一旦生体から遊離され， これで移植する場合，尿管への血流はやがて膀胼側か らも行われるようになると考兄らるが，イヌを用いた Texter ${ }^{9)}$ の実験では自家移植でも 4 週間を要するといわ
れ, 術後の早い時期のものでは, もし変化があつても拒 絶反応を含めての解釈は困難と思われる.

\section{結語}

腎移植患者に対し，濃縮試験，ピトレッシン負荷テス ト; Cosm/GFR, 尿管口の 観察を行い, 膀胱尿管逆流現 象の有無; 排泄性尿路造影を行つた。濃縮能は, 提供者 の術前, 術後は変らないが, 受腎者では拒絶反応の有無 によつて異なる值を示した。

ピトレッシンに対する反応パターンは, 提供者によつ て特徵を有し, これが受腎者に移植された場合は, 特に 拒絶反応，ATN などがなければ，特徵がそのまま伝承 されている．拒絶反応をみた例では反応は鈍化する。 GFR 当りの浸透圧クリアランスは, 拒絶反応を示した 群では上昇していた。 また尿管口の観察では, 膀脱粘膜 との移行がスムーズにみられる例, 不自然にみられる例 があり，拒絶反応の有無が関係しているものと思われ た。膀胼尿管逆流現象は移植腎へはみられず，排泄性尿 路造影は全例正常であつた. 著者らの成績は, 臨床経過 とよく相関しているところから, 移植腎機能は皮質機能 のみならず，髄質機能を代表する諸成績をるつて評価す ることも必要であることを強調したい。

（稿を終るにのぞみ，測定に協力された金沢医科大学 泌尿器科三井智津枝, 青地真知嬢拉よび中央検查部諸氏 に感謝いたします。

本論文の要旨は, 第 $64,65,67$ 回日本泌尿器科学会総 会, 第290, 294回北陸地方会, 第12,14回日本移植学会 総会, 第 4, 9, 10回中部臟器移植談話会に打いて逐次 発表した。

な拈本研究の一部は文部省科学研究費補助金, 昭和 51 年度167211号によつた，付記して感謝する).

\section{文献}

1）金井泉，金井正光：腎機能検査法，臨床検査 法提要, 第27版, XIV 30-31, 金原出版, 東京, 1975.

2) Massry, S.G., Schainuck, L.I., Goldsmith, C. and Schreiner, G.E.: Studies on the mechanism of diuresis after relief of urinary tract obstruction. Ann. Int. Med., 66, 149$158,1967$.

3）津川龍三，鈴木孝治，山川義憲，近沢秀幸，松 浦一: 泌尿器科領域に怙けるピトレッシン負 荷テストについて。目泌尿会誌, 67, 729, 1976.

4) 田近栄司, 鈴木孝治, 山川義憲, 松浦一, 津 川龍三: 腎移植例飞打ける尿管膀胱新吻合につ いて一その 臨床的観察一. 移植, 13, 246$250,1978$. 
5) Ogden, D.A.: Donor and recipient function 2-4 years after renal homotransplantation, Paired study of 28 cases. Ann. Int. Med., 67, 998-1006, 1967.

6) 小川秋実 : 腎髄質検査の問題点. 池上圭一 編, 堅機能検査, 107-132, 南山堂, 東京, 1974.

7) 安東明夫, 井上 朗 : 腎機能検査の精度, 評価, 判定. 尿比重, 尿量. 綜合臨床, 24, 566-
571, 1975.

8) Williams, G.M., White, H.J.O. and Hume, D.M.: Factors influencing the long term functional success rate of human renal allografts. Transplantation, 5, pt 2, 837-843, 1967.

9) Texter, J.H.: The isolated ureter, A model of ureteral rejection. Urology, 2, 244-248, 1973.

（1979年 4 月 7 日受付） 